\title{
Transactional costs of the interaction between business and government as a threat to the economic security of the state
}

\author{
Aleksandr Evmenov 1,*, Svetlana Kuzmina ${ }^{1}$, Marina Vlasova $^{2}$ and Olga Stepchenkova ${ }^{3}$ \\ ${ }^{1}$ Saint Petersburg State Institute of Film and Television. 13, Pravdy Street, Saint Petersburg, Russia \\ ${ }^{2}$ Saint-Petersburg State University of Economics, 21, Sadovaya Street, Russia \\ ${ }^{3}$ Saint Petersburg International Banking Institute. 60, Nevsky Avenue, Saint Petersburg, Russia
}

\begin{abstract}
The article considers the costs of the interaction between the state and business as a threat to the development of the economy of the Russian Federation from the point of view of ensuring economic security. The authors identified significant obstacles both from the business and from the government side, which pose a threat to economic security. The study is of interest for the further development of a system of providing the economic security of the Russian Federation.
\end{abstract}

\section{Introduction}

The effectiveness of entrepreneurship in the task of strengthening the economic stability of the state and stimulating economic growth is justified in the works of many researchers.

The American economist R. Coase, Nobel Prize winner, believed that "the firm is effective, because it can reduce transaction costs (associated costs) in the production and sale of goods and services and be competitive". The theoretical bases of the study of transaction costs were suggested by R. Coase in his works "The Nature of a Firm" and "Problems of Social Costs" [1, 2]. An economic organization arises when the internal transaction costs are less than the costs of using a market mechanism.

The development of the organization continues until the internal transaction costs are equal to the external transaction costs or until they become the same as similar costs in competitors' companies. Thus, the development and functioning of the organization is a consequence of the effectiveness of the realized transaction costs, and the result of a balance between the costs of adaptation and the costs of coordination.

According to the "Theory of the Firm" by R. Coase, economic agents experience transaction costs. It is quite obvious that in the economic system of interaction between the state and business transaction costs also arise.

Based on this idea, M.A. Alekseev defines economic security as a built-in mechanism for reconciling the costs of adaptation and the costs of coordination to achieve the sustainable functioning and development of an organization.

\footnotetext{
*Corresponding author: kuzmina2003@bk.ru
} 
The activities to ensure economic security are aimed at reducing the costs of adaptation associated with the specificity of assets, behavioral uncertainty, and the uncertainty of the external economic environment, as well as the costs of coordination - administrative costs [3].

O.A. Marina and N.K. Moiseeva note that there is a tendency to increase transaction costs in a nation's GDP in the economies of the world's leading countries. The interaction of knowledge-based business with state structures is accompanied by a large number of bureaucratic costs, which play a decisive role in the development of the strategy of young enterprises [8].

A.A. Komkova and A.E. Shastitko found that today there is no single standard for the quantitative assessment of transaction costs at the macroeconomic level (both in terms of the choice of the time interval and in terms of the way of classifying activities [6]).

According to the research of G.P. Litvintseva and N.A. Gakhova, the growth of transaction costs can have both a positive and a negative impact on the growth of gross domestic product, depending on the structure of the economy [7].

Thus, from a position of economic security, transaction costs can become a threat to the development of the economy. Within the framework of economic security, the study of these transaction costs can help to identify and neutralize economic threats.

\section{Research methodology and statistics}

This study uses the principle of systematic research work, and the connection between theory and practice. The scientific and theoretical basis of this project is a number of publications and studies of domestic and foreign scientists. The research uses data from official statistical observation and expert studies.

Within the framework of the Saint Petersburg Economic and Social Development Strategy for the Period until 2030 (approved by the resolution of the Government of Saint Petersburg of May 13, 2015 No. 355), the development of Small to Medium Enterprises (SMEs) is one of the priority directions and important drivers for ensuring the sustainable economic growth and innovative development of Saint Petersburg. The infrastructure of SMEs support is actively developing in Saint Petersburg in five main directions: financial, property, legal, information support and consulting, and export support. In 2010, the Center for the Development and Support of Entrepreneurship, under the Committee for the Development of Entrepreneurship and the Consumer Market of the Government of Saint Petersburg, was established in Saint Petersburg.

The Center is a multidisciplinary organization that provides a wide range of services for entrepreneurs on the principle of "one-stop shopping". It provides consulting, conducts training seminars, and offers protection to SMEs in priority areas of the region's development (for example, in light industry).

It is premature to judge the effectiveness in reducing administrative barriers through the "Single Window" Center. In addition, according to the business community in Russia, there are other organizations that could perform similar functions (Table 1).

The study revealed that the issue of entrepreneurship promotion is not sufficiently developed. The population needs direct contact with the government to establish a trusting relationship. A constructive dialogue between business and government needs to be established. People should be motivated to go to SMEs, engage in entrepreneurship, and benefit the city and the country. The effectiveness of any promotional information is made up of two factors: the quality of the information itself and the demand for the product that the information promulgates. 
Table 1. Organizations that in the Opinion of Entrepreneurs Could Effectively Perform the Functions of a "Single Window" (Source: compiled by the authors).

\begin{tabular}{|l|l|}
\hline Name of organization & Share of votes \\
\hline Multifunctional Center & $35,9 \%$ \\
\hline $\begin{array}{l}\text { Single digital platform on the basis of } \\
\text { "State information system Industry" } \\
\text { ("GIS Industry") } \\
\text { or portal of the State Service }\end{array}$ & $18,8 \%$ \\
\hline Industrial Development Fund & $16,2 \%$ \\
\hline Regional Fund for the Development of Industry & $16,2 \%$ \\
\hline $\begin{array}{l}\text { Regional Agency / } \\
\text { Corporation Development / } \\
\text { Enterprise Support Fund }\end{array}$ & $13,7 \%$ \\
\hline Specially Created Federal Agency & $11,1 \%$ \\
\hline Regional Executive Authorities & $7,7 \%$ \\
\hline
\end{tabular}

State and municipal government bodies in the Russian Federation employ about 400 thousand people, of which, according to Rosstat (Russian Federal State Statistics Service), only $10 \%$ have an education in the specialty "State and municipal management".

The situation with education in the field of entrepreneurship (with the exception of lawyers and accountants) is no better.

Any person can become an entrepreneur or a director of a company, and he takes upon himself the risks of interaction with the state, regardless of the size of the company.

Thus, development of the economy should come from two spheres that utilize different and diametrically opposed work methods.

These spheres can hardly find mutual understanding and common ground.

The inefficiency of interaction is an obstacle to ensuring the economic security of the state and is expressed in the form of uselessly spent budgetary funds, unrealized and unnecessary projects, and constant changes in legislation.

According to the World Bank, the state and business in the Russian Federation are losing up to $1.8 \%$ of GDP for exercising control and supervisory functions. In addition, existing pressure from the state forces more than $50 \%$ of SMEs to work in the "shadow economy" [4].

The innovative activity of enterprises is at a low level (9\%). In adverse business conditions, only $5 \%$ of start-ups manage to keep their business afloat. Despite the abovementioned problems, the population of Saint Petersburg and Russia as a whole has a significant staffing potential for creating innovative entrepreneurship, which is proven by the following:

- There are 350 students per 10 thousand people;

- 54\% of citizens aged 25 to 64 have higher education [4].

This suggests that innovative entrepreneurship can be developed in Russia with the support of the state and municipal authorities.

\section{Features of GR-management development}

Government relations are usually understood as the interaction of large companies or industry organizations with state authorities, which allow them to build long-term relations, establish dialogue including participation in drafting sectoral laws.

GR-specialists work for one large company or association, and monitor the opportunities and risks coming from governmental structures. 
Since it is at the early stage of formation in Russia, GR-management, as a division of management, has not yet acquired the form of a single structured system. However, GRmanagement is reflected in the works of Russian researchers [9, 10].

The specificity of Russian GR is that the largest customer of goods and services is the state, which means that lack of mutual understanding with the authorities often cuts off business representatives from government contracts. On the basis of the computational data of the Global Competitiveness Index (first is best), Russia occupies 102nd place in the indicators "payments and corruption", 87th place in "favoritism in decisions of officials", and "transparency of state policy"- 68th place (all indicators - from 144 countries) [5].

This indicates the existence of corrupt state structures and, accordingly, the existence of shadow lobbying in industry. The authors conducted a study of 7748 resumes of applicants for the position of GR-Manager on the websites https://www.superjob.ru and https://hh.ru, and identified the following results:

$80 \%$ of applicants are in the age group of 30 and older;

$66 \%$ of applicants have higher education;

$48.6 \%$ do not disclose the desired level of income;

$97.9 \%$ are citizens of Russia, the rest - citizens of other countries;

$66.9 \%$ are ready for full time work;

$78.5 \%$ have more than 6 years of experience; $17.8 \%$

The largest number of applicants is in Moscow - 63.3\% and in Saint Petersburg -

Applicants have named their key skills: project management (34.6\%), negotiation (32.1\%), organizational skills $(31.8 \%)$ and others $(1.5 \%)$.

Negative experience of communication with state structures forces entrepreneurs to refuse state support or to seek the services of GR-specialists, and/or lobbyists. Services for interaction with the authorities are carried out by individual specialists offering their assistance, or by GR-companies lobbying to influence the decisions of the authorities (executive, legislative and judicial) in favor of the customer. In the Russian Federation, lobbying is not legislatively regulated, but this profession is represented on the job market.

The main activities of the GR-specialist are to:

- Influence with the aim of amending the legislation or introducing new laws into the State Duma, obtaining preferences and tax incentives;

- Increase the number of contacts with representatives of authority (publicity) with the purpose of raising the interest of the mass media and the population;

- Accompany the company upon receipt of state orders and participation in tenders;

- Attract the attention of controlling and law enforcement agencies to the activities of competitors;

-Overcome obstacles and limitations of business development.

Private costs of enterprises for the services of the GR-manager are monthly, depending on the experience of the specialist and the functions performed by him (from 30 to 150 thousand rubles and higher).

In Russia, GR-management exists only in the structures of large business: gas, oil, pharmaceutical, telecommunications, automotive, etc. Small enterprises, as a rule, operate without GR-management.

\subsection{The economic security of the state from the standpoint of transaction costs of interaction between business and government}

The study revealed that enterprises and authorities face a number of obstacles; that is, they bear transaction costs in the process of interaction with each other.

These costs represent a threat to the economic security of the state. 
This threat should be understood as the possibility of damaging the national economy as a whole and its branches in particular, the financial and credit system of the state; the possibility of violating the socio-economic stability of society and the economic situation of the individual.

An analysis of the relations between business and government showed that the ineffective work of state structures contributes to the growth of the lobbying services sector, which does not always fall under the taxation regime, and the refusal of entrepreneurs to use state support mechanisms that, according to the theory of economic security, pose a threat.

The system of economic security of the Russian Federation contains the following main activities:

- Information and analytical (monitoring of economic threats, assessment of the current state of economic security with the help of the system of indicators; forecasting);

- Regulatory measures (improvement of the regulatory framework, elimination of crisis situations);

- Direct measures (state programs, state regulation, and counteraction to bearers of threats).

\section{Results}

Within the framework of the system of ensuring economic security, an integrated approach to identifying and assessing the transaction costs of business and government cooperation will contribute to the development of entrepreneurship and the enhancement of the sustainability of the Russian economy.

It is quite obvious that the effective interaction of the authorities in support of SMEs will contribute to strengthening the economic security of the state, and on the contrary, unsuccessful attempts of entrepreneurs to establish contact with the bureaucracy and useless state support measures will lead to the formation of new threats.

\section{Conclusions}

The development of SMEs in the Russian Federation is a fundamental problem. Efforts of the state authorities to involve the population in the development of their own businesses are currently ineffective. The expectations of the population to ensure economic well-being are not related to their own initiative and are mainly dependent upon the state's activities to create jobs and improve living standards. The current situation represents a clear threat to the development of the economy and should be thoroughly studied by specialists in economic security.

According to the authors, the fact of transaction costs of interaction between the state and business, which are of scientific interest as an object of research in economic security, is confirmed. Data are given that characterize the existence of the low assessment of the work of state structures by entrepreneurs; low activity of the population in organizing their own business; and a significant number of applicants for the position of GR-manager in the absence of appropriate legislative support.

\section{References}

1. R.H. Coase, Economica 4, 10 (1937)

2. R.H. Coase, Journal of Law and Economics, 3 (1960) 
3. M.A. Alekseev, Journal of Contemporary Problems in Science and Education, 4 (2014)

4. URL : http://www.ebrd.com/beeps

5. URL : http://gtmarket.ru/ratings/global-competitiveness-index/info

6. URL : https://archive.econ.msu.ru/sys/raw.php?o=3554\&p=attachment

7. URL : http://cyberleninka.ru/article/n/dinamika-transaktsionnogo-sektora-ekonomikirossii-kak-uchil-d-nort

8. URL : https://creativeconomy.ru/lib/4680

9. V.V. Okrepilov, S.N. Kuzmina, V.L. Makarov, A.R. Bakhtizin, Economy of Region, 2 (2015)

10. URL : http://elar.urfu.ru/bitstream/10995/43629/1/978-5-7996-1806-3_2016.pdf

11. P.A. Tolstykh, SISP. 2013, 1(21) (2013) 